\title{
The levels of sICAM-1, sELAM-1, TNFa and sTNFR1 proteins in patients with colorectal adenocarcinoma in tumor and corresponding normal mucosa
}

\author{
Joanna Katarzyna Strzelczyk1, Piotr Cuber1, Benjamin Bochon'1, Krzysztof Gajdzik1, \\ Janusz Strzelczyk ${ }^{2}$, Łukasz Krakowczyk ${ }^{3}$, Andrzej Wiczkowski ${ }^{5}$, Aleksander Jerzy Owczarek ${ }^{4}$ \\ and Zofia Ostrowska ${ }^{1}$
}

1Department of Medical and Molecular Biology, Faculty of Medical Sciences in Zabrze, Medical University of Silesia in Katowice, Zabrze, Poland 2Department of Endocrinology and Neuroendocrine Tumors, Department of Pathophysiology and Endocrinology, Faculty of Medical Sciences in Zabrze, Medical University of Silesia in Katowice, Katowice, Poland; ${ }^{3}$ Clinic of Oncological and Reconstructive Surgery, Maria SklodowskaCurie Memorial Cancer Center and Institute of Oncology, Gliwice, Poland; ${ }^{4 H e a l t h ~ P r o m o t i o n ~ a n d ~ O b e s i t y ~ M a n a g e m e n t ~ U n i t, ~ D e p a r t m e n t ~ o f ~}$ Pathophysiology, Faculty of Medical Sciences in Katowice, Medical University of Silesia in Katowice, Katowice, Poland; ${ }^{5}$ nniversity of Technology, Faculty of Medicine, Katowice, Poland

Colorectal cancer is a common malign disease of the gastrointestinal tract. The cancer survival rate depends on the stage of the disease at detection time. It is well known that several molecular mechanisms are involved in cancer and some molecules might affect or modulate cancerogenesis. The aim of the study was to assess the levels of sICAM-1, sELAM-1, TNFa and sTNFR1 protein in tumor and corresponding normal mucosa in a group of patients with colorectal adenocarcinoma and also associations of these parameters with demographic and clinical profiles of the patients. Tissue specimens were obtained during resection of neoplastic lesions. Protein levels were assayed in tissue homogenates by ELISA. The protein level of sICAM-1 in tumor was significantly increased in comparison to the corresponding normal mucosa $(80.06 \mathrm{ng} / \mathrm{mg}$ vs $69.53 \mathrm{ng} / \mathrm{mg}, p=0.02$ ). Furthermore, a significant positive correlation between sICAM-1 and sTNFR1 proteins levels in tumor $\left(r_{s}=0.58, p<0.001\right)$ and in corresponding normal mucosa $\left(r_{s}=0.48, p<0.001\right)$ was found. Also, significant correlations in corresponding normal mucosa were found between SELAM-1 and SICAM-1 $\left(r_{s}=0.58, p<0.001\right)$ and between sTNFR1 and sELAM- $1\left(r_{s}=0.57, p<0.001\right)$. Significantly higher level of sTNFR1 in corresponding normal mucosa samples of patients with distant metastases was observed $(p=0.04)$. Obtained results suggest that sICAM-1 protein could be considered as colorectal cancer marker. Furthermore, sTNFR1 also has the potential to become a good prognostic marker used during monitoring of the patients. Nevertheless, a further study in this area to confirm this correlation is required.

Key words: sICAM-1, sELAM-1, TNFa, sTNFR1, proteins, colorectal cancer

Received: 04 September, 2020; revised: 27 October, 2020; accepted: 29 October, 2020; available on-line: 26 November, 2020

曰e-mail: jstrzelczyk@sum.edu.pl

Abbreviations: CAMs, cell adhesion molecules; CD62E, CD62 antigen-like family member E; CRC, colorectal cancer; ELAM-1, endothelial-leukocyte adhesion molecule-1; ELISA, Enzyme-Linked Immunosorbent Assay; ICAM-1, intercellular adhesion molecule-1; ICAMs, intercellular adhesion molecules; IL-1 $\beta$, interleukin-1 $\beta$; LECAM2, leukocyte-endothelial cell adhesion molecule 2; NAFs, normal tissue-associated fibroblasts; sELAM-1, soluble endothelialleukocyte adhesion molecule-1; sICAM-1, soluble intercellular adhesion molecule-1; sTNFR1, soluble tumor-necrosis factor receptor 1; TAFs, tumor-associated fibroblasts; TNFa, tumor necrosis factor alfa; TNFR1, tumor-necrosis factor receptor 1; TNFR2, tumor-necrosis factor receptor 2

\section{INTRODUCTION}

Colorectal cancer (CRC) is a common malign disease of the colon and rectum (Labianca et al., 2010). In 2002, almost 530000 death cases of colorectal cancer were reported, which made up to about $8 \%$ of all deaths from cancer, although generally the mortality rate in the western countries was declining. Ten years later, the number of deaths was already 700000 . According to predictions, in 2030 the number of deaths will increase to 1100000 (Arnold et al., 2017). The cancer survival rate depends strongly on the stage of the disease at detection time. $90 \%$ of patients with localized stage survive 5 years, but only $10 \%$ with remote metastases manage to survive this period (Haggar \& Boushey, 2009). Factors believed to be involved in the risk of developing colorectal cancer can be divided into modifiable ones, such as diet, obesity, lack of physical activity, tobacco use, moderateto-heavy alcohol use and non-modifiable ones, such as personal or familial history of colorectal polyps or CRC, hereditary conditions such as Lynch syndrome, a personal history of inflammatory bowel disease, racial and ethnic backgrounds, and the presence of type 2 diabetes. Moreover, a significant risk factor is age, since $90 \%$ of new cases are reported in individuals over 50 years old (Simon, 2016). It is well known that several molecular mechanisms are involved in cancer development and metastasis. A lot of studies indicate that the following molecules may influence the process of carcinogenesis: intercellular adhesion molecule-1 (ICAM-1), endothelialleukocyte adhesion molecule-1 (ELAM-1), tumor necrosis factor alfa $(\mathrm{TNF}-\alpha)$ and tumor-necrosis factor receptor 1 (TNFR1) (Sawada et al., 1994; Wang \& Yong, 2008).

Intercellular adhesion molecules (ICAMs, also referred to as CD45) are cellular ligands for leukocyte $\beta_{2}$-integrins and are responsible for intracellular communication and immune reactions (Gahmberg et al., 1997). There are five already identified representatives of ICAMs which differ in their distribution among various cell types (Gahmberg et al., 1997). ICAM-1 is expressed constitutively at low levels on the vascular endothelium and on some lymphocytes and monocytes. It was found also in other non-hematopoietic cells (Hubbard \& Rothlein, 2000; Huang et al., 2004). Up-regulation of ICAM-1 gene takes place in response to such pro-inflammatory cytokines as 
IL-1 $\beta$, TNF- $\alpha$ and IFN- $\gamma$ (Myers et al., 1992; Huang et al., 2004). A lot of studies showed a significant impact of ICAM-1 on CRC development (Wimmenauer et al., 1997; Alexiou et al., 2001; Maeda et al., 2002; Taglia et al., 2007; Mantur et al., 2009).

ELAM-1 (endothelial-leukocyte adhesion molecule-1), also known as E-selectin, CD62E (CD62 antigen-like family member E) or LECAM2 (leukocyte-endothelial cell adhesion molecule 2), is one of cell adhesion molecules (CAMs) being expressed on inflammatory-activated endothelial cells. E-selectin is responsible for cell adhesion, taking part in recruiting neutrophils, monocytes, and memory $\mathrm{T}$ cells to the site of injury (Bevilacqua et al., 1987; Banks et al., 1993, Muraki et al., 1996). ELAM-1 expression is induced by TNF- $\alpha$ or IL-1 $\beta$ and increased further by $\gamma$-interferon (Banks et al., 1993). Elevated Eselectin levels have been reported in many tumor types, especially in solid tumors with co-existing ulceration (Banks et al., 1993; Muraki et al., 1996).

TNF $\alpha$ (tumor necrosis factor alfa) also called cachexin or cachectin is a cytokine regulating immune cell survival and function via $\mathrm{NF}-x \mathrm{~B}$ and MAPK pathways and produced by many types of cells, including activated macrophages and cancer tissue itself (Zins et al., 2007; Hnatyszyn et al., 2019). It exerts cytotoxicity on many lines of tumor cells, inhibits tumorigenesis and promotes immunological response (Wajant et al., 2003). TNF $\alpha$ has the ability to bind two receptors: TNFR1 (called also TNF receptor type 1, TNF-R, TNF-R-I, CD120a, p55/60) and TNFR2 (TNF receptor type 2, TNF-R-II, CD120b, p75/80). TNFR1 is proved to be expressed constitutively in most tissues, whereas TNFR2 is found mostly in immune system cells. The wide range of TNF- $\alpha$ functions can be explained by the presence of these receptors on nearly all cell types (Zins et al., 2007; Hnatyszyn et al., 2019). TNFR can be found on most human cells and is considered the receptor through which most of the pro-inflammatory effects are elicited. The interaction between TNF- $\alpha$ and TNFR1 triggers important signaling pathways inducing diverse cellular phenomena including inflammation, apoptosis, etc. (Wajant et al., 2003). Soluble forms of TNFR1 and TNFR2, which are proteolytically cleaved from extracellular domains, have TNF $\alpha$ neutralizing capacity, since they can bind with the ligand and thus counteract biding of $\mathrm{TNF} \alpha$ to the cellular receptors (Van Zee et al., 1992).

ICAM-1, ELAM-1 and TNFR1 exist primarily in cell membrane-bound forms where they act mostly as aiders of inflammatory process and help leukocytes infiltrate from the blood stream into the inflammation site (Bevilacqua et al., 1987; Banks et al., 1993; Wajant et al., 2003; Taglia et al., 2007). However, apart from their membrane-bound forms, these molecules have their soluble forms that are present in the serum. Paradoxically, these soluble forms were proven to disrupt the process of leukocytes infiltration as they bind into the same ligands and prevent leukocytes from migrating into the targeted tissue. Thus, instead of impairing cancer development and subsequent metastasis they actually help with this process (Lauri et al., 1991; Van Zee et al., 1992; Sawada et al., 1994; Izumi et al., 1995; Kitagawa et al., 1998; Alexiou et al., 2001; Kang et al., 2005; Mantur et al., 2009). Therefore, the aim of the study was assessing the protein levels of sICAM-1, sELAM-1, TNF $\alpha$ and sTNFR1 in tumor and corresponding normal mucosa in a group of patients with colorectal adenocarcinoma. We also evaluated the association between mentioned protein levels and demographic and clinical factors; such as age, gender, tumor location and size, stage of the tumor ac- cording to Duke's staging system, grade (G), nodal metastasis and distant metastasis, and 5-year survival rate.

\section{MATERIALS AND METHODS}

Patients and samples. The study group included 47 patients aged 26-82 years (the average 65 years) with a preoperative diagnosis of colorectal cancer based on imaging studies and histopathological examination of specimens. Women constituted $43 \% \quad(\mathrm{~N}=20)$ of the study group, and men 57\% (N=27). Tobacco smokers, patients with gastro-intestinal tract, pancreatic and liver diseases, diabetes, lipid metabolism disorders and acute infections were excluded from the research population. Hereditary and family factors associated with the development of colorectal cancer were also excluded. Patients did not receive any pre-operative radio-chemotherapy.

Tissue specimens from both tumor and corresponding normal mucosa, were obtained during the resection of neoplastic lesions in the Clinic of Oncological and Reconstructive Surgery of the Maria Sklodowska-Curie Memorial Cancer Centre \& Institute of Oncology, Gliwice Branch, Poland. A corresponding normal mucosa was obtained from a distal segment of resected colon, in a distance of at least $2 \mathrm{~cm}$ from the tumor. The mean distance of distal corresponding normal mucosa was 4.49 $\mathrm{cm}$. The specimens were placed on ice and forthwith transported to the laboratory where they were washed twice with cold $0.9 \% \mathrm{NaCl}$ solution. Subsequently, fragments were frozen at $-80^{\circ} \mathrm{C}$.

Collected during resection second fragments were examined histopathologically. Histopathological evaluation of the samples was conducted at the Tumor Pathology Department of the Maria Sklodowska-Curie Memorial Cancer Centre \& Institute of Oncology, Gliwice Branch, Poland. The presence of colorectal adenocarcinoma was histopathologically confirmed, while the presence of neoplastic cells in the distal corresponding normal mucosa was excluded. In $79 \%$ of cases $(\mathrm{N}=37)$ the tumor was found in the distal section of the colon, while in $21 \%$ of individuals $(\mathrm{N}=10)$ tumors were located in the proximal section (the borderline was set at the splenic flexure). Average tumor size in the study group was 4.67 $\mathrm{cm}$. Patients were divided into two subgroups depending on the stage of the tumor according to Duke's scale. The first subgroup consisted of $27(57 \%)$ patients with $\mathrm{A}$ and B Duke's stages; the second subgroup consisted of $20(43 \%)$ patients with C and D Duke's stages. Histopathological evaluation revealed that $11(24 \%)$ cases had well differentiated (G1) cancer, $33(70 \%)$ cases had moderately differentiated (G2) cancer, and $3(6 \%)$ poorly differentiated (G3) cancer. The examination did not reveal the presence of any lymphocytic infiltration in the area surrounding the tumors, thus ruling out local inflammation. The research project was approved by the Bioethics Committee of the Maria Sklodowska-Curie Memorial Cancer Centre \& Institute of Oncology, Gliwice Branch at the meetings of the Committee Nos. D0/DGP/49310/05 and KB/493-54/07. All patients familiarized themselves with the protocol and signed informed consent document to participate in the study.

Tissue homogenization and total protein concentration. Fragments of tumor and corresponding normal mucosa were weighted and homogenized using PRO 200 homogenizer (PRO Scientific Inc., USA) at $10000 \mathrm{rpm}$ in nine volumes of PBS (BIOMED, Poland) containing $0.5 \%$ Triton $^{\circledR}$ X-100 (Sigma-Aldrich ${ }^{\circledR}$, USA). Secondly, the suspensions were sonicated with an ultrasonic cell 
Table 1. The levels of sICAM-1, sELAM-1, TNFa and sTNFR1 proteins in tissue homogenates from tumor and corresponding normal mucosa in a group of patients with colorectal cancer.

Significant correlations are given in bold.

\begin{tabular}{|c|c|c|c|}
\hline Protein level & Tumor Me (Q1-Q3) & Corresponding normal mucosa Me (Q1-Q3) & $p$ value \\
\hline sICAM-1 (ng/mg protein) & $80.06(50.99-146.20)$ & $69.53(38.62-99.39)$ & 0.02 \\
\hline sELAM-1 (ng/mg protein) & $3.18(2.71-4.62)$ & $3.19(2.16-5.34)$ & 0.81 \\
\hline TNFa (pg/mg protein) & $7.16(4.39-10.29)$ & $6.26(3.78-8.26)$ & 0.24 \\
\hline sTNFR1 (ng/mg protein) & $0.76(0.53-1.21)$ & $0.76(0.59-1.10)$ & 0.85 \\
\hline
\end{tabular}

Me stands for median, Q1 stands for lower quartile, Q3 stands for upper quartile

disrupter (UP 100, Hilscher, Germany). Subsequently, the homogenates were centrifuged at $12000 \mathrm{rpm}$ for 15 minutes at $+4^{\circ} \mathrm{C}$. The total protein concentration was determined using pyrogallol-red method by reagent kit for direct colorimetric measurements of total protein (Sentinel Diagnostics, Italy). Readings were taken at $600 \mathrm{~nm}$ wavelength at $37^{\circ} \mathrm{C}$ using Technicon RA-XT'TM biochemical analyzer (Technicon Instruments Corporation, USA).

Enzyme-Linked Immunosorbent Assay (ELISA). Protein levels were assayed in homogenates by Enzyme-Linked Immunosorbent Assay (ELISA) according to the manufacturer's procedure. The sICAM-1 and sELAM-1 (CD62E) levels were assayed by the Diaclone ELISA Kit (France), the TNF $\alpha$ level by the Immundiagnostik TNF $\alpha$ ELISA Kit (Germany), and s'TNFR1 level by human sTNFR1 (60kDa) ELISA BMS203CE (Bender MedSystems, Austria). Absorbance readings were obtained with ELISA PowerWave XS ${ }^{\mathrm{TM}}\left(\right.$ BioTek $^{\circledR}$, USA) at $450 \mathrm{~nm}$ wavelength and calibrated according to the standard curve in $\mathrm{ng} / \mathrm{ml}$ ( $\mathrm{TNF} \alpha$ in $\mathrm{pg} / \mathrm{ml}$ ). The obtained results were recalculated to the corresponding total protein concentration. All samples were analyzed in duplicates.

Statistical analysis. Statistical analysis was performed using STATISTICA v. 13.36.0 (StatSoft, Cracow, Poland). Statistical significance was set at a $p$-value below 0.05 . Data was presented as mean value \pm standard deviation in case of normal distribution and with median and lower/upper quartile in other cases. Distribution of variables was evaluated by the Shapiro-Wilk's test, and homogeneity of variances was assessed by the Levene's test. In case of skewed data distribution, logarithmic transformation was done before analysis. Categorical variables were compared using $\chi^{2}$ test. T-Student test for normal data distribution and U Mann-Whitney test for other type of data distribution were done for comparison of quantitative data. Dependable values were compared by $t$-Student or Wilcoxon test depending on the data distribution. The assessment of association between clinical status and protein levels was done with the multivariable linear regression and the backward-stepwise procedure. Spearman's rank correlation coefficient $\left(r_{s}\right)$ was calculated to evaluate association between examined parameters.

\section{RESULTS}

The results of comparison of protein levels between the tumor and corresponding normal mucosa are presented in Table 1. The protein level of the adhesion molecule sICAM-1 was significantly increased in tumor samples with the median value of $80.06 \mathrm{ng} / \mathrm{mg}$ against $69.53 \mathrm{ng} / \mathrm{mg}$ in the corresponding normal mucosa samples, $(p=0.02$; Table 1$)$.

Significant positive correlation between sICAM-1 and s'TNFR1 proteins levels was found in tumors and in corresponding normal mucosa $\left(r_{\mathrm{s}}=0.58, p<0.001, \mathrm{r}_{\mathrm{s}}=0.48\right.$, $p<0.001$; respectively, Table 2 and Table 3). Furthermore, significant positive correlations between sICAM-1 and sELAM-1 $\left(\mathrm{r}_{\mathrm{s}}=0.58, p<0.001\right)$ and sTNFR1 and sELAM-1 $\left(\mathrm{r}_{\mathrm{s}}=0.57, p<0.001\right)$ were found in the corresponding normal mucosa (Table 3).

No association was found between levels of selected proteins and demographic and clinical parameters; such as age, gender, tumor location and size, stage of the tumor according to Duke's staging system, grade $(G)$, nodal metastasis and distant metastasis, and 5-year survival rate, with the exception of sTNFR1. It was found that patients with distant metastases had significantly higher s'TNFR1 level in corresponding normal mucosa in comparison to patients without distant metastases $[1.22$ (0.76-1.49) vs 0.65 (0.52-1.03); $p=0.04$, Mann-Whitney U-test].

\section{DISCUSSION}

Many molecular events involving a process of initiation and formation of colorectal cancer have already been well described. They comprehend primarily genetic and epigenetic alterations that activate oncogenes and inactivate tumor suppressor genes. The most common gene expression changes seen in colorectal cancer include genes involved in the following signaling pathways: WNT signaling, MAPK signaling, PI3K signaling, TGF $\beta$ signaling, and p53 signaling. It is also postulated that gene mutations result in the formation of cancer stem cells, which are essential for initiation and maintenance of a tumor (Kuipers et al., 2015). A detailed analysis that is supposed to be used for prediction of tumor progression ability has to include not only analysis of tumor cell

Table 2. Spearman rank correlation coefficient $\left(r_{s}\right)$ values for sICAM-1, sELAM-1, TNFa and sTNFR1 protein levels in tumors. Significant correlations are given in bold.

\begin{tabular}{|c|c|c|c|c|}
\hline Variable & sICAM-1 & sELAM-1 & TNFa & sTNFR1 \\
\hline sICAM-1 & 1.00 & 0.36 & -0.02 & 0.58 \\
\hline sELAM-1 & 0.36 & 1.00 & 0.06 & 0.22 \\
\hline TNFa & -0.02 & 0.06 & 1.00 & -0.11 \\
\hline sTNFR1 & 0.58 & 0.22 & -0.11 & 1.00 \\
\hline
\end{tabular}


Table 3. Spearman rank correlation coefficient $\left(r_{s}\right)$ values for sICAM-1, sELAM-1, TNFa and sTNFR1 protein levels in corresponding normal mucosa.

Significant correlations are given in bold.

\begin{tabular}{|c|c|c|c|c|}
\hline Variable & sICAM-1 & sELAM-1 & $\mathrm{TNFa}$ & sTNFR1 \\
\hline sICAM-1 & 1.00 & 0.58 & 0.20 & 0.48 \\
\hline sELAM-1 & 0.58 & 1.00 & 0.32 & 0.57 \\
\hline TNFa & 0.20 & 0.32 & 1.00 & 0.37 \\
\hline sTNFR1 & 0.48 & 0.57 & 0.37 & 1.00 \\
\hline
\end{tabular}

phenotype, but also tumor microenvironment-related information. Inflammation is a one of the important factors in the development and progression of a cancer. Tumor-infiltrating inflammatory cells secrete a variety of proteins that can induce growth-promoting and angiogenesis-promoting factors (Galon et al., 2014; Kuipers et al., 2015). An extensive body of research works underlines the crucial influence of a host immune system on colorectal cancer development (Pages et al., 2005; Galon et al., 2006; Galon et al., 2007; Pages et al., 2009; Mlecnik et al., 2011; Angell \& Galon, 2013).

A lot of prognostic molecular and cellular biomarkers of colorectal cancer have already been proposed and tested, such as microsatellite instability; LINE-1 hypomethylation; mutations of $B R A F, K R A S$, and $A P C$ genes; characterization of $\mathrm{CD}^{+}, \mathrm{CD}^{+}$and $\mathrm{CD} 45 \mathrm{RO}^{+}$ tumor infiltrating cells (Galon et al., 2014; Mármol et al., 2017), as well as many adhesion molecules such as vascular endothelial growth factor, E-cadherin, CD24, CD44, osteopontin and epithelial cell adhesion molecule (Broll et al., 2001; Chai et al., 2015; Seo et al., 2015). In our study, we aimed to assess the utility of the following protein levels as prognostic factors: sICAM-1, sELAM-1, TNF $\alpha$, sTNFR1. Colorectal cancer is associated with inflammatory process and other anti-tumor reactions not only in the tumor but also in the surrounding tissue, called corresponding normal mucosa (Wittig et al., 1997; Maurer et al., 1998). Therefore, we decided to compare levels of these potential prognostic proteins both in tumor and surrounding tissue. The interaction between inflammatory processes and the development of malignancy seems to be connected with the soluble forms of the studied molecules, as well as molecular mechanisms involved in cancer metastasis (Wittig et al., 1997; Maurer et al., 1998). Due to a low number of corresponding studies, various approaches and methodology used in other research works, we decided to compare our results also with studies presenting other cases (other biological material and other types of cancer) yet, still focused on proteins of our interest (sICAM-1, sELAM-1, sTNF $\alpha$ and sTNFR1).

In our report, we have found elevated sICAM-1 protein level in the colorectal cancer tissue in comparison with the corresponding normal mucosa sample. Upregulation of ICAM-1 in cancer tissue has already been described by many authors. Schellerer and others (Schellerer et al., 2014) compared an expression pattern of tumor-associated fibroblasts (TAFs) and normal tissueassociated fibroblasts (NAFs) isolated respectively from colorectal cancer and healthy colorectal tissue in terms of ICAM-1 expression. The number of ICAM-1-positive fibroblasts was significantly higher in TAFs than in NAFs. Moreover, interleukin-1 $\beta$ (IL-1 $\beta$ ) stimulation resulted in significantly greater increase of ICAM-1-positive cells in TAFs group when compared to NAFs. Furthermore, isolated TAFs displayed a higher than NAFs adhesion capacity for tested monocytic cells. To confirm increased expression of ICAM-1 in original tumor tissue, Schellerer and others (Schellerer et al., 2014) conducted also immunohistochemical staining which indicated significant margin of ICAM-1-positive fibroblast residing tumor environment when compared to normal mucosa. Presented findings and our results support the hypothesis that inflammation process (detected here by increased ICAM-1 expression) fosters host's reaction against the tumor by adhesion of infiltrating antitumor immune cells. The presence of peritumoral inflammation in colon carcinoma was shown to be positively correlated with the expression of ICAM-1. Moreover, Kelly and others (Kelly et al., 1992) concluded that ICAM-1 might have played a role in leukocyte trafficking and epithelium-leukocytes interplay (Kelly et al., 1992). It was confirmed by Maurerand others (Maurer et al., 1998), who also found that the presence of ICAM-1 in small blood vessels and matrix of the tissue within colorectal cancer could favor extravasation and adhesion of cytotoxic lymphocytes to neoplasmal cells which was responsible for anti-tumor reaction in the host. Furthermore, ICAM-1-positive fibroblasts may stabilize the tumor and thus, reduce its progression (Schellerer et al., 2014). A few reports have already showed that increased membrane-bound ICAM1 was correlated with decreased lymph node metastases and better differentiated tumors as well (Wimmenauer et al., 1997; Maeda et al., 2002; Taglia et al., 2007). Yang's et al. (2015) study indicates that a decrease in ICAM-1 mRNA expression may influence the malignancy and aggressiveness of the colorectal cancer. The above presented findings may suggest a dependence of ICAM-1 expression on a tumorigenesis process and the protein itself might be used as an indicator to predict the course of that process.

Membrane-bound ICAM-1 is believed to impair metastasis via preventing cells from detaching from the primary tumor. Moreover, membrane-bound ICAM-1 expression by cancer cells in CRC correlates positively with tumor differentiation level (Taglia et al., 2007). On the other hand, many researchers indicate the important role of soluble form of ICAM-1 (sICAM-1). The level of sICAM-1 is significantly positively correlated with tumor stage and the appearance of metastasis (Kitagawa et al., 1998; Alexiou et al., 2001; Kang et al., 2005; Mantur et al., 2009). The mechanisms involved in sICAM-1 formation have not been completely elucidated. It is proposed that sICAM-1 may be generated by proteolytic cleavage from membrane-bound ICAM-1, although several studies demonstrated the presence of specific mRNA transcripts coding for sICAM-1 in cells (Wakatsuki et al., 1995; Champagne et al., 1998; Lyons \& Benveniste, 1998; Witkowska \& Borawska, 2004). Interesting results were showed by Maruo and others (Maruo et al., 2002) who studied ICAM-1 expression and the level of soluble ICAM-1 (sICAM-1) in gastric patients at different stages of the disease. They reported that the serum ICAM-1 level of gastric cancer patients was significantly higher 
than that of healthy volunteers. They also found that the sICAM-1 level was significantly higher in patients with liver metastasis than in patients without liver metastasis. Such results suggested that ICAM-1 was overexpressed in cancer cells and subsequently released in a form of sICAM-1, which would then promote hematogenous metastasis by suppressing local anticancer immunity (Maruo et al., 2002). What is more, Komatsu and others (Komatsu et al., 1997) proved that plasma concentration of ICAM-1 does not accurately reflect the level of its expression on the cells. Nevertheless, the level of serum ICAM-1 seems to be a good diagnostic feature, as our studies confirm its significantly elevated levels in tumors in comparison to normal mucosa. The presence of elevated sICAM-1 may be related to disease-associated differences in the regulation of inflammatory process in colorectal cancer.

Another protein of our interest was sELAM-1. We did not find any significant difference between the level of sELAM-1 in the tumor and corresponding normal mucosa of colorectal cancer patients. A few studies showed relatively higher serum levels of E-selectin in colorectal cancer patients and suggested that the E-selectin-mediated binding of colorectal cancer cells to human endothelium correlates with tumor progression and the formation of blood-transferred metastases (Lauri et al., 1991; Sawada et al., 1994; Izumi et al., 1995). In a report of Alexiou and others (Alexiou et al., 2001), significantly higher ELAM-1 (as well as ICAM-1) serum level in colorectal cancer patients when compared to healthy individuals was showed. Moreover, E-selectin serum levels correlated positively with ICAM-1 serum levels, disease stage and the presence of both lymph node and visceral metastatic disease (Alexiou et al., 2001). Another study by Wittig and others (Wittig et al., 1997), who investigated sICAM-1 and sELAM-1 expression in tumor as well as nonmalignant cell lines, showed sICAM-1 upregulation as a response to sELAM-1 pretreatment in tumor cell lines, but not in related nonmalignant cells, indicating a tumor-specific mechanism. In our study, we also show a significant positive correlation between sICAM-1 and sELAM-1 $\left(\mathrm{r}_{\mathrm{s}}=0.58, p<0.001\right)$ but only in normal mucosa. In the cancer tissue, the levels of both proteins display a positive correlation as well $\left(r_{s}=0.36\right)$, however, statistical significance is missing. Interesting results were presented by Maurera and others (Maurer et al., 1998) who showed elevated levels of ICAM-1, V-CAM-1 and ELAM-1 mRNA within colorectal cancer tissue compared to normal tissue. It was explained that elevated expression of ICAM-1 may be preventing cell-cell disruption and as a result the tumor dissemination. They also stated that elevated expression of ICAM-1 and VCAM-1 but not ELAM-1 might be favoring the host anti-tumor defense by trafficking of lymphocytes (Maurer et al., 1998). The problem is that the study deals with the membranebound forms of these proteins, which makes it difficult to compare to our studies. Nevertheless, it confirms the complexity of ELAM-1 involvement in the process of carcinogenesis or metastasis.

The reason for discrepancies between the above presented literature data on the levels of ELAM-1 and our results might be explained by the study by Sawada and others (Sawada et al., 1994), who found that not so much the concentration of ELAM-1 as the presence and expression of suitable ligands for this protein, such as sialyl Lewis $\mathrm{x}$ and LAMP molecules, are important for its activity. Another problem is that two different forms of this protein, soluble and membrane-bound, present quite different physiological activity (Wittig et al., 1997).
Therefore, the level of its expression might not be sufficient enough to be a good prognostic or diagnostic factor on its own. Our results indicate that the problem of ELAM-1 involvement is more complicated and needs to be studied further.

$\mathrm{TNF} \alpha$ is known to trigger oncogenic signal pathways in epithelial cells regulating their growth and survival (Wang et al., 2008). It displays a pro-tumorigenic activity in the development of colorectal cancer (Klampfer, 2011). Activation of $\mathrm{TNF} \alpha$ provides, through the expression of ELAM-1 and a surface sialyl carbohydrate Lewis $x$ and $a$, an adhesion of cancer cells to vascular endothelium. Subsequently, initial adhesion molecules, like ICAM and VCAM, deliver solid adhesion in a chronic inflammation during tumor-promoting process (Dianzani et al., 2008). So far, few studies proved overexpression of TNF $\alpha$ in CRC tissues as well as a positive correlation between TNF $\alpha$ levels and the CRC progression and reduced patient survival. Obeed et al. (2014) confirmed a significantly higher expression of TNF $\alpha$ (at both mRNA and protein level) in colorectal cancer tissue in relation to adjacent normal tissue $(\mathrm{N}=30)$. Researchers showed a strong correlation between elevated TNF $\alpha$ expression and advanced tumor stages (stage III and IV). Just as in our study, all the patients having undergone any additional therapy collaterally to surgical treatment were excluded from the study (Obeed et al., 2014). Zins and others (Zins et al., 2007) confirmed there was a correlation between the expression of $\mathrm{TNF} \alpha \mathrm{mRNA}$ and the occurrence of colorectal cancer within the colon tissue. $\mathrm{TNF} \alpha$ influenced many processes such as, cell death regulation, cell proliferation and inflammation. Despite the fact that $T N F \alpha$ is able to initiate apoptosis within the tumor, these capabilities are repeatedly deactivated. In some cases, TNF $\alpha$ stimulates the survival of cancer cells, and that property is known as tumor promoting. Moreover, an over-expressed TNF $\alpha$ can enhance the metastatic activity of tumor cell lines (Zins et al., 2007).

TNF receptors (including TNFR1) can be found on most human cells and their interaction with TNF $\alpha$ presents wide range of effects (Wajant et al., 2003; Zins et al., 2007; Hnatyszyn et al., 2019). TNFR1 is known to be responsible for tumor-suppressive activity of $\mathrm{TNF} \alpha$, whereas TNFR2 role seems to be quite different and still underestimated. It is found mostly on suppressive immune cells, including regulatory $\mathrm{T}$ cells and myeloid-derived suppressor cells and some tumor cells. Contrary to TNFR1, TNFR2 seems to be tumor-promoting instead of tumor-supressing factor (Wajant et al., 2003; Sheng et al., 2018). We are planning to include this protein, among others in further research and analyses. Equally important is soluble form of TNFR1, since its interaction with TNF $\alpha$ can give different effects to its cell-bound form (Van Zee et al., 1992), thus sTNFR1 was another protein included in our analysis. We found significantly higher level of sTNFR1 in corresponding normal mucosa samples of patients with distant metastases. Significantly higher serum concentration of soluble TNFR1 in patients with colorectal adenomas in comparison with control group was found by Hosono and others (Hosono et al., 2012) as a promising biomarker for that tumor. Moreover, it was also confirmed that TNFR1 presents high levels of diagnostic sensitivity and specificity in patients with colorectal cancer (Hosono et al., 2012). A correlation between soluble forms of TNFR1 and ICAM-1 in tumor has been found in our studies, we have also found a significant correlation between these molecules also in the normal mucosa. Viac and others (Viac et al., 1996) also found correlation between soluble forms of 
TNFR1 and ICAM-1 in malignant melanoma. A strong positive correlation was found in the tumors, while it was weak in the normal mucosa. These correlations may suggest a physiological dependence of those molecules on one another and their participation in either tumorigenesis or cancer development. sELAM-1 might be involved as well, as positive significant correlations between this protein and both sTNFR1 and sICAM-1 were found in the corresponding normal mucosa. Most probably the development of cancer takes place when dynamic balance between the expression levels of these three proteins is disrupted. Moreover, sTNFR1 might be used as a prognostic factor of the severity of the disease and a possibility of metastases occurrence, as its level was found to be higher in patients with distant metastases. Nevertheless, further studies in this area to confirm these correlations are required.

Based on the results of our research the level of sICAM-1 molecule was significantly increased in tumors in comparison to normal mucosa. It might possibly be used as an additional indicator to help distinguish between the tumor and corresponding normal mucosa. It seems that none of the studied proteins can be an efficient marker on its own and when considering their levels only. In order to increase the efficiency of diagnosis and prognosis, the whole microenvironment should be analyzed. This would have to include the levels of not only soluble forms but also membrane-bound forms of these proteins, as well as their ligands (especially in the case of sELAM-1) and some additional proteins. Nevertheless, further studies are needed to confirm whether this course of action would be the right one and also to study further the involvement of these and similar proteins in the process of tumor formation, development and metastasis occurrence, as still our knowledge in this regard seems not efficient enough. The differences in the regulation and activity of the selected molecules can be factors in defining cancer but additional work is needed to determine the specificity of these potential biomarkers. Further studies would need to include, apart from already mentioned factors, such as levels of expression of both membrane-bound and soluble forms of the proteins and their ligands, also other proteins, such as VCAM-1 or TNFR2, comparative material from healthy individuals, as well as sample analysis from the same patients after tumor removal, bigger study group might be needed too.

\section{Acknowledgements}

Not applicable.

\section{Authors' contributions}

JKS - research concept and design; JKS, ŁK - collection and/or assembly of data; JKS, PC, JS, AJO - data analysis and interpretation; JKS, PC, BB, KG, JS - writing the article; AW, $\mathrm{ZO}$ - critical revision of the article. All authors - final approval of the article.

\section{Competing interests}

The authors declare that they have no competing interests.

\section{REFERENCES}

Alexiou D, Karayiannakis AJ, Syrigos KN, Zbar A, Kremmyda A, Bramis I, Tsigris C (2001) Serum levels of E-selectin, ICAM-1 and VCAM-1 in colorectal cancer patients: correlations with clinico- pathological features, patient survival and tumour surgery. Eur I Cancer 37: 2392-2397. https://doi.org/10.1016/s0959-8049(01)00318-5

Angell HK, Galon J (2013) From the immune contexture to the Immunoscore: the role of prognostic and predictive immune markers in cancer. Curr Opin Immunol 25: 261-267. https://doi.org/10.1016/j. coi.2013.03.004

Arnold M, Sierra MS, Laversanne M, Soerjomataram I, Jemal A, Bray F (2017) Global patterns and trends in colorectal cancer incidence and mortality. Gut 66: 683-691. https://doi.org/10.1136/ gutjnl-2015-310912

Banks RE, Gearing AJ, Hemingway IK, Norfolk DR, Perren TJ, Selby PJ (1993) Circulating intercellular adhesion molecule-1 (ICAM-1), Eselectin and vascular cell adhesion molecule-1 (VCAM-1) in human malignancies. Br J Cancer 68: 122-124. https://doi.org/10.1038/ bjc. 1993.298

Bevilacqua MP, Pober JS, Mendrick DL, Cotran RS, Gimbrone MA (1987) Identification of an inducible endothelial-leukocyte adhesion molecule. Proc Natl Acad Sci U S A 84: 9238-9242. https://doi. org/10.1073/pnas.84.24.9238

Broll R, Erdmann H, Duchrow M, Oevermann E, Schwandner O, Markert U, Bruch HP, Windhövel U (2001) Vascular endothelial growth factor (VEGF) - a valuable serum tumour marker in patients with colorectal cancer? Eur J Surg Onco 27: 37-42. https://doi. org/10.1053/ejso.2000.1052

Chai XB, Song RF, Xu F (2015) Expression changes in epithelial cell adhesion molecule during colorectal cancer tumorigenesis. Genet Mol Res 14: 7624-7629. https://doi.org/10.4238/2015.July.13.6

Champagne B, Tremlay P, Cantin A, St. Pierre I (1998) Proteolytic cleavage of ICAM-1 by human neutrophil elastase. I Immunol 161: 6398-6405

Dianzani C, Brucato L, Gallicchio M, Rosa AC, Collino M, Fantozzi R (2008) Celecoxib modulates adhesion of HT29 colon cancer cells to vascular endothelial cells by inhibiting ICAM-1 and VCAM-1 expression. Br J Pharmacol 153: 1153-1161. https://doi.org/10.1038/ sj.bjp.0707636

Gahmberg CG, Tolvanen M, Kotovuori P (1997) Leukocyte adhesion-structure and function of human leukocyte beta2-integrins and their cellular ligands. Eur J Biochem 245: 215-232. https://doi. org/10.1111/j.1432-1033.1997.00215.x

Galon J, Mlecnik B, Bindea G, Angell HK, Berger A, Lagorce C, Lugli A, Zlobec I, Hartmann A, Bifulco C, Nagtegaal ID, Palmqvist R, Masucci GV, Botti G, Tatangelo F, Delrio P, Maio M, Laghi L, Grizzi F, Asslaber M, D'Arrigo C, Vidal-Vanaclocha F, Zavadova E, Chouchane L, Ohashi PS, Hafezi-Bakhtiari S, Wouters BG, Roehrl M, Nguyen L, Kawakami Y, Hazama S, Okuno K, Ogino S, Gibbs P, Waring P, Sato N, Torigoe T, Itoh K, Patel PS, Shukla SN, Wang Y, Kopetz S, Sinicrope FA, Scripcariu V, Ascierto PA, Marincola FM, Fox BA, Pagès F (2014) Towards the introduction of the 'immunoscore' in the classification of malignant tumours. J Pathol 232: 199-209. https://doi.org/10.1002/path.4287

Galon J, Costes A, Sanchez-Cabo F, Kirilovsky A, Mlecnik B, LagorcePagès C, Tosolini M, Camus M, Berger A, Wind P, Zinzindohoué $\mathrm{F}$, Bruneval P, Cugnenc $\mathrm{P}$, Trajanoski Z, Fridman W, Pagès F (2006) Type, density, and location of immune cells within human colorectal tumors predict clinical outcome. Science 313: 1960-1964. https://doi.org/10.1126/science.1129139

Galon J, Fridman WH, Pages F (2007) The adaptive immunologic microenvironment in colorectal cancer: a novel perspective. Cancer Res 67: 1883-1886. https://doi.org/10.1158/0008-5472.CAN-06-4806

Haggar FA, Boushey RP (2009) Colorectal cancer epidemiology: incidence, mortality, survival, and risk factors. Clin Colon Rectal Surg 22: 191-197. https://doi.org/10.1055/s-0029-1242458

Hnatyszyn A, Hryhorowicz S, Kaczmarek-Ryś M, Lis E, Słomski R, Scott RJ, Pławski A (2019) Colorectal carcinoma in the course of inflammatory bowel diseases. Hered CancerClin Pract 17: 18. https:// doi.org/10.1186/s13053-019-0118-4

Hosono K, Yamada E, Endo H, Takahashi H, Inamori M, Hippo Y, Nakagama H, Nakajima A (2012) Increased tumournecrosis factor receptor 1 expression in human colorectal adenomas. World J Gastroenterol 38: 5360-5368. https://doi.org/10.3748/wig.v18.i38.5360

Huang W, Chan S, Yang T, Tzeng C, Chen C (2004) Inhibition of ICAM-1 gene expression, monocyte adhesion and cancer cell invasion by targeting IKK complex: molecular and functional study of novel alpha-methylene-gamma-butyrolactone derivatives. Carcinogen 25: 1925-1934. https://doi.org/10.1093/carcin/bgh211

Hubbard AK, Rothlein R (2000) Intercellular adhesion molecule-1 (ICAM-1) expression and cell signaling cascades. Free Radic Biol Med 28: 1379-1386. https://doi.org/10.1016/s0891-5849(00)00223-9

Izumi Y, Taniuchi Y, Tsuji T, Smith CW, Nakamori S, Fidler IJ, Irimura T (1995) Characterization of human colon carcinoma variant cells selected for sialyl Lex carbohydrate antigen: liver colonization and adhesion to vascular endothelial cells. Exp Cell Res 216: 215-221. https://doi.org/10.1006/excr.1995.1027

Kang X, Wang F, Xie JD, Cao J, Xian PZ (2005) Clinical evaluation of serum concentrations of intercellular adhesion molecule-1 in 
patients with colorectal cancer. World I Gastroenterol 11: 4250-4253. https://doi.org/10.3748/wjg.v11.i27.4250

Kelly CP, O`Keane JC, Orellana J, Schroy PC, Yang S, LaMont JT, Brady HR (1992) Human colon cancer cells express ICAM-1 in vivo and support LFA-1-dependent lymphocyte adhesion in vitro. Am J Physiol 263: 864-870. https://doi.org/10.1152/ajpgi.1992.263.6.G864

Kitagawa T, Matsumoto K, Iriyama K (1998) Serum cell adhesion molecules in patients with colorectal cancer. Surg Today 28: 262-267. https://doi.org/10.1007/s005950050118

Klampfer L (2011) Cytokines, inflammation and colon cancer. Curr Cancer Drug Targets 11: 451-464

Komatsu S, Flores S,Gerritsen ME, Anderson DC, Granger DN (1997) Differential up-regulation of circulating soluble and endothelial cell intercellular adhesion molecule-1 in mice. Am J Pathol 151: 205-214

Kuipers EJ, Grady WM, Lieberman D, Seufferlein T, Sung JJ, Boelens PG, van de Velde CJH, Watanabe T (2015) Colorectal cancer. Nat Rev Dis Primers 1: 15065. https://doi.org/10.1038/nrdp.2015.65

Labianca R, Beretta GD, Kildani B, Milesi L, Merlin F, Mosconi S, Pessi MA, Prochilo T, Quadri A, Gatta G, de Braud F, Wils J (2010) Colon cancer. Crit Rev Oncol Hematol 74: 106-133. https:// doi.org/10.1016/j.critrevonc.2010.01.010

Lauri D, Needham L, Martin-Padura I, Dejana E (1991) Tumor cell adhesion to endothelial cells: endothelial leukocyte adhesion molecule- 1 as an inducible adhesive receptor specific for colon carcinoma cells. J Natl Cancer Inst 83: 1321-1324. https://doi.org/10.1093/ jnci/83.18.1321

Lyons PD, Benveniste EN (1998) Cleavage of membraneassociated ICAM-1 from astrocytes: involvement of metalloprotease. Glia 22: 103-112. https://doi.org/10.1002/(sici)1098-1136(199802)22:2

Maeda K, Kang SM, Sawada T, Nishiguchi Y, Yashiro M, Ogawa Y, Ohira M, Ishikawa T, Chung KH (2002) Expression of intercellular adhesion molecule- 1 and prognosis in colorectal cancer. Oncol Rep 9: $511-514$

Mantur M, Snarska J, Koper O, Dzieciol J, Plonski A, Lemancewicz D (2009) Serum sICAM, sVCAM and sE-selectin levels in colorectal cancer patients. Folia Histochem Cytobiol 47: 621-625. https://doi. org/10.2478/v10042-009-0077-0

Mármol I, Sánchez-de-Diego C, Pradilla Dieste A, Cerrada E, Rodriguez Yoldi MJ (2017) Colorectal carcinoma: a general overview and future perspectives in colorectal cancer. Int J Mol Sci 18: 197. https://doi.org/10.3390/ijms18010197

Maruo Y, Gochi, A, Kaihara A, Shimamura H, Yamada T, Tanaka N, Orita K (2002) ICAM-1 expression and the soluble ICAM-1 level for evaluating the metastatic potential of gastric cancer. Int J Cancer 100: 486-490. https://doi.org/10.1002/ijc.10514

Maurer CA, Friess H, Kretschmann B, Wildi S, Műller C, Graber H, Schilling M, Bűchler MW (1998) Over-expression of ICAM1, VCAM-1 and ELAM-1 might influence tumourprogression in colorectal cancer. Int J Cancer 79: 76-81. https://doi.org/10.1002/ (sici) 1097-0215(19980220)79:1<76::aid-ijc15>3.0.co;2-f

Mlecnik B, Tosolini M, Kirilovsky A, Berger A, Bindea G, Meatchi T, Bruneval P, Trajanoski Z, Fridman WH, Pagés F, Galon J (2011) Histopathologic-based prognostic factors of colorectal cancers are associated with the state of the local immune reaction. J Clin Oncol 29: 610-618. https://doi.org/10.1200/JCO.2010.30.5425

Muraki J, Kobayashi M, Sugaya Y, Hashimoto S, Morita T, Kobayashi Y, Tokue A (1996) Role of serum E-selectin (ELAM-1) and inflammatory parameters in patients with renal cell carcinoma. Nihon Hinyokika Gakkai Zasshi 87: 831-841. https://doi.org/10.5980/jpnjurol1989.87.831

Myers CL, Wertheimer SJ, Schembri-King J, Parks T, Wallace RW (1992) Induction of ICAM-1 by TNF-alpha, IL-1 beta, and LPS in human endothelial cells after downregulation of PKC. Am I Physiol 263: 767-772. https://doi.org/10.1152/ajpcell.1992.263.4.C767

Obeed OAA, Alkhayal KA, Sheikh AA, Zubaidi AM, Vaali-Mohammed M, Boushey R, Mckerrow JH, Abdulla M (2014) Increased expression of tumournecrosis factor-a is associated with advanced colorectal cancer stages. World J Gastroenterol 48: 18390-18396. https://doi.org/10.3748/wjig.v20.i48.18390

Pages F, Berger A, Camus M, Sanchez-Cabo F, Costes A, Molidor R, Mlecnik B, Kirilovsky A, Nilsson M, Damotte D, Meatchi T, Bruneval P, Cugnenc P, Trajanoski Z, Fridman WH, Galon J (2005) Effector memory $\mathrm{T}$ cells, early metastasis, and survival in colorec- tal cancer. N Engl J Med 353: 2654-2666. https://doi.org/10.1056/ NEJMoa051424

Pages F, Kirilovsky A, Mlecnik B, Asslaber M, Tosolini M, Bindea G, Lagorce C, Wind P, Marliot F, Bruneval P, Zatloukal K, Trajanoski Z, Berger A, Fridman WH, Galon J (2009) In situ cytotoxic and memory $\mathrm{T}$ cells predict outcome in patients with early-stage colorectal cancer. I Clin Oncol 27: 5944-5951. https://doi.org/10.1200/ JCO.2008.19.6147

Sawada R, Tsuboi S, Fukuda M (1994) Differential E-selectin-dependent adhesion efficiency in sublines of a human colon cancer exhibiting distinct metastatic potentials. I Biol Chem 269: 1425-1431

Schellerer VS, Langheinrich M, Hohenberger W, Croner RS, Merkel S, Rau TT, Stűrzl M, Naschberger E (2014) Tumor-associated fibroblasts isolated from colorectal cancer tissues exhibit increased ICAM-1 expression and affinity for monocytes. Oncol Rep 31: 255261. https://doi.org/10.3892/or.2013.2860

Seo K, Kim M, Kim J (2015) Prognostic implications of adhesion molecule expression in colorectal cancer. Int J Clin Exp Pathol 8: 4148-4157

Sheng Y, Li F, Qin Z (2018) TNF receptor 2 makes tumor necrosis factor a friend of tumors. Front. Immunol. 9: 1170. https://doi. org/10.3389/fimmu.2018.01170

Simon K (2016) Colorectal cancer development and advances in screening. Clin Interv Aging 11: 967-976. https://doi.org/10.2147/ CIA.S109285

Taglia L, Matusiak D, Matkowskyj KA and Benya RV (2007) Gastrin-releasing peptide mediates its morphogenic properties in human colon cancer by upregulating intracellular adhesion protein-1 (ICAM-1) via focal adhesion kinase. Am I Physiol Gastrointest Liver Physiol 292: G182-G190. https://doi.org/10.1152/ajpgi.00201.2006

Van Zee KJ, Kohno T, Fischer E, Rock CS, Moldawer LL, Lowry SF (1992) Tumour necrosis factor soluble receptors circulate during experimental and clinical inflammation and can protect against excessive tumour necrosis factor a in vitro and in vivo. Proc Natl Acad Sci U S A 89: 4845-4849. https://doi.org/10.1073/pnas.89.11.4845

Viac J, Vincent C, Palacio S, Schmidt D, Claudy A (1996) Tumour necrosis factor (TNF) soluble receptors in malignant melanoma: correlation with soluble ICAM-1 levels. Eur I Cancer 32: 447-449. https://doi.org/10.1016/0959-8049(95)00541-2

Wajant H, Pfizenmaier K, Scheurich P (2003) Tumournecrosis factor signaling. Cell Death Differ 10: 45-65. https://doi.org/10.1038/ sj.cdd.4401189

Wakatsuki T, Kimura K, Kimura F, Shinomiya N, Ohtsubo M, Ishizawa M, Yamamoto M (1995) A distinct mRNA encoding a soluble form of ICAM-1 molecule expressed in human tissues. Cell Adhes Commun 3: 283. https://doi.org/10.3109/15419069509081014

Wang X, Yong L (2008) Tumournecrosis factor and cancer, buddies or foes? Acta Pharmacol Sin 29: 1275-1288. https://doi.org/10.1111/ j.1745-7254.2008.00889.x

Wimmenauer S, Keller H, Rückauer KD, Rahner S, Wolff-Vorbeck G, Kirste G, von Kleist S, Farthman EH (1997) Expression of CD44, ICAM-1 and N-CAM in colorectal cancer. Correlation with the tumor stage and the phenotypical characteristics of tumor-infiltrating lymphocytes. Anticancer Res 17: 2395-2400.

Witkowska AM, Borawska MH (2004) Soluble Intercellular Adhesion molecule-1 (sICAM-1): An Overview. Eur Cytokine Netw 15: 91-98

Wittig BM, Treichel U, Blaheta R, Schreiter T, Schwarting A, Meyer zum Bűschenfelde KH, Mayet W (1997) Soluble E-selectin enhances intercellular adhesion molecule-1 (ICAM-1) expression in human tumor cell lines. Exp Cell Res 237: 364-370. https://doi. org/10.1006/excr.1997.3786

Yang M, Liu J, Piao C, Shao J, Du J (2015) ICAM-1 suppresses tumourmetastasis by inhibiting macrophage M2 polarization through blockade of efferocytosis. Cell Death Dis 6: e1780. https://doi. org/10.1038/cddis.2015.144

Zins K, Abraham D, Sioud M, Aharinejad S (2007) Colon cancer cellderived tumournecrosis factor-alpha mediates the tumourgrowthpromoting response in macrophages by up-regulating the colonystimulating factor-1 pathway. Cancer Res 67: 1038-1045. https:// doi.org/ 10.1158/0008-5472.CAN-06-2295 